\title{
Adult Mesenchymal Stem Cells and Cell Surface Characterization - A Systematic Review of the Literature
}

\author{
P. Mafi ${ }^{1}$, S. Hindocha ${ }^{*, 2,3}$, R. Mafi ${ }^{1}$, M. Griffin ${ }^{2}$ and W.S. Khan ${ }^{4}$ \\ ${ }^{I}$ The Hull York Medical School, Heslington, York YO10 5DD, UK \\ ${ }^{2}$ Manchester Interdisciplinary Biocentre, University of Manchester, 131 Princess Street, M17DN, UK \\ ${ }^{3}$ Department of Plastic Surgery, Whiston General Hospital, Liverpool, L355DR, UK \\ ${ }^{4}$ University College London Institute of Orthopaedics and Musculoskeletal Sciences, Royal National Orthopaedic \\ Hospital, Stanmore, Middlesex, HA7 4LP, UK
}

\begin{abstract}
Human adult mesenchymal stem cells (MSCs) were first identified by Friedenstein et al. when observing a group of cells that developed into fibroblastic colony forming cells (CFU-F). Ever since, the therapeutic uses and clinical applications of these cells have increased research and interest in this field. MSCs have the potential to be used in tissue engineering, gene therapy, transplants and tissue injuries. However, identifying these cells can be a challenge. Moreover, there are no articles bringing together and summarizing the cell surface markers of MSCs in adults. The purpose of this study is to summarize all the available information about the cell surface characterization of adult human MSCs by identifying and evaluating all the published literature in this field. We have found that the most commonly reported positive markers are CD105, CD90, CD44, CD73, CD29, CD13, CD34, CD146, CD106, CD54 and CD166. The most frequently reported negative markers are CD34, CD14, CD45, CD11b, CD49d, CD106, CD10 and CD31. A number of other cell surface markers including STRO-1, SH2, SH3, SH4, HLA-A, HLA-B, HLA-C, HLA-DR, HLA-I, DP, EMA, DQ (MHC Class II), CDIO5, Oct 4, Oct 4A, Nanog, Sox-2, TERT, Stat-3, fibroblast surface antigen, smooth muscle alpha-actin, vimentin, integrin subunits alpha4, alpha5, beta1, integrins alphavbeta3 and alphavbeta5 and ICAM-1 have also been reported. Nevertheless, there is great discrepancy and inconsistency concerning the information available on the cell surface profile of adult MSCs and we suggest that further research is needed in this field to overcome the problem.
\end{abstract}

Keywords: Bone marrow derived multipotent progenitor cells; cell surface profile; mesenchymal stem cells; surface markers.

\section{INTRODUCTION}

About 130 years ago, the German pathologist Cohneim proposed the existence of non-hematopoietic stem cells in the bone marrow. He suggested that these cells could contribute to wound healing as they can be a source of fibroblasts [1]. Later, Friedenstein et al. identified human adult mesenchymal stem cells when observing a group of cells that developed into fibroblastic colony forming cells (CFU-F) [2]. Friedenstein provided strong evidence for the self-renewal potential of stem cells by demonstrating their ability to regenerate heterotropic bone tissue. These findings have been confirmed and expanded by many further laboratory studies which have shown that the cells isolated by Friedenstein can also be found in human bone marrow and could differentiate into a range of different mesenchymal lineage cells including chondrocytes, adipocytes, myoblasts and osteoblasts [1,3-6].

Simmons et al. found that stromal cells supporting hematopoiesis were different to hematopoietic cells by showing that sexmismatched HLA-identical cells from patients solely expressed the host genotype [7]. This again supports Friendenstein's findings showing hematopoietic

*Address correspondence to this author at the Manchester Interdisciplinary Biocentre, University of Manchester, 131 Princess Street, M17DN, UK; Tel: 01244366265; Fax: 01244366277; E-mail: hindocha2001@yahoo.com stem cells were physically different from transplanted sexmismatched cells capable of heterotropic osseous tissue formation [8]. Now that these cells are found to be different, research is being done to identify whether there exist specific cell surface antigens to identify phenotypic differences between mesenchymal and hematopoietic stem cells. Even though many mesenchymal stem cell surface antigens have been cultured, there have been very few in vivo phenotypic characterization of MSCs [9]. Bianco et al. conducted one of the first studies with the intention of characterizing MSClike cells both histologically and phenotypically. Interestingly, it has been shown that a wide range of nonhematopoietic stem cells exist in the bone marrow and that MSC are merely a subset of this population. These include "multipotent adult progenitor cells" (MAPCs), "endothelial progenitor cells" (EPCs), "marrow-isolated adult mutilinease inducible cells" (MIAMI), " very small embryonic-like stem cells" (VSELs) [9-13].

Crisan et al. has found that multipotent mesenchymal stem cells exist in many different human organs [14]. To support this fact, it has been shown that MSCs are not confined to bone marrow and can also be found in placenta, dental pulp, tendons, skeletal muscle, fat, umbilical cord blood and amniotic fluid [14-22]. Despite the common belief that mesenchymal stem cells are derived from the embryonic mesoderm, a recent study by Takashima and colleagues showed that the earliest lineage of MSC-like cells are 
developed, at least in part, from Sox $1(+)$ neuroepithelium through a neural crest intermediate stage rather than from mesoderm [23]. These cells have been shown to be replaced by MSCs in later development. Nagoshi and colleagues have recently demonstrated that neural crest-derived cells migrate through the bloodstream to the bone marrow [24]. These cells are present in the bone marrow and can develop into myofibroblasts, glial cells and neurons. Further research is needed to assess whether there is a link between cells indentified by Friedenstein and those identified by Takashima and colleagues [25].

Various studies have demonstrated the potential use if MSCs in gene therapy, transplants due to their special immunogenic properties and tissue injuries. Current research aims at characterizing, expanding and identifying ways to keep MSCs in the undifferentiated state, with the intention of transplanting them back to repair bone and cartilage [26-31]. Phinney and Prockop argue that mesenchymal stem cells could form the basis for a highly potent "natural system of tissue repair" [32]. Many further experimental models of tissue injuries have demonstrated the therapeutic properties of MSCs upon exogenous administration [33-37]. Prockop pointed out to an interesting fact that in the greater proportion of studies, there has been no correlation between the therapeutic effectiveness and the engraftment efficacy [38]. Furthermore, his findings suggest that the ability to repair was secondary to secretion of soluble factors by MSCs that changed the environment of the tissue [38]. Adult human mesenchymal stem cells have also been shown to have non-immunogenic surface antigens, due to possessing major histocompatibility complex class I protein (MHC I) instead of MHC II [39]. This is undoubtedly a valuable characteristic of adult MSCs which could make it possible to transplant them into an allogenic host without any need for immunosuppression [25]. Many attempts have also been done in order to apply MSCs in gene therapy. This includes their application in Lobstein disease in humans upon systemic administration [40, 41]. Nevertheless, extensive research needs to be done in this field, as our knowledge about their potential use in gene therapy is still very primitive. Also, not much is known about the phenotypic character, developmental origin and their contribution to organogenesis; an assay to demonstrate their selfrenewability in vivo is still missing [25].

The therapeutic uses and clinical applications of MSCs have increased research and interest in identifying these cells. Despite $1 \%$ of the bone marrow population consisting of hematopoietic cells only $1 / 10000$ to $1 / 100000$ of the bone marrow nuclear cells are MSCs [42, 43]. Moreover, there is not adequate information about the cell surface markers of adult mesenchymal stem cells and how they can be identified. Therefore, correct identification of these cells can be a challenge. There are no articles bringing together and summarizing the cell surface markers of mesenchymal stem cells in adults. The purpose of this study is to summarize all the available information about the cell surface characterization of adult human mesenchymal stem cells by identifying and evaluating all the published literature in this field. The studies reporting mesenchymal stem cell surface markers were searched predominantly using Medline, CINAHL (EBSCO), ZETOC, PubMed, EMBASE and
AMED. This systematic review is intended to provide a good basis for identification and selection of adult human mesenchymal stem cells.

\section{MATERIALS AND METHOD}

The studies referencing the cell surface markers of adult mesenchymal cells were searched using the electronic databases Medline, CINAHL (EBSCO), ZETOC, PubMed, EMBASE, AMED, PREMEDLINE In-Process \& NonIndexed Citations (OvidSP), ASSIA (CSA Illumina), Conference Proceedings Citation Index: Science (ISI) on Web of Knowledge, PsycINFO (OvidSP), Science Citation Index (ISI) on Web of Knowledge, Social Sciences Citation Index (ISI) on Web of Knowledge and Cochrane Library (Wiley). The following keywords were used to cite relevant articles: adult mesenchymal stem cells, bone marrow-derived multipotent progenitor cells, cell surface profile, MSCs, surface markers. The inclusion criteria were based on 1) characterization of cell surface markers of mesenchymal stem cells 2) identifying mesenchymal stem cells in adults. Studies were excluded which 1) did not comment on the cell surface character of mesenchymal stem cells 2) did not involve mesenchymal stem cells 3 ) identified mesenchymal stem cells in non adults, or embryo 4) were not available for free viewing. A total of 138 articles were reviewed. 29 articles were identified as relevant according to the inclusion criteria. These studies were summarized and the relevant information is presented in Tables 1-5.

\section{RESULTS}

29 studies were identified as relevant according to the inclusion criteria, out of the 138 articles reviewed. Subsequently, these were reviewed carefully and the results summarized in Tables $\mathbf{1}$ and $\mathbf{2}$.

As can be seen in Table 1, twenty nine studies looked at mesenchymal cells from different tissues and also identified various cell surface markers characterizing the cells. For easier interpretation, the cell surface markers identified by each study were summarized in Table 2. Gronthos et al. [45] stated that adult human bone marrow stromal stem cells (BMSSCs) or mesenchymal stem cells are non-cyclical and express telomerase activity [45]. Tsai et al. [19] identified the expression of SH2, SH3, SH4 and HLA-ABC (MHC class I) in addition to CD29, CD44, CD90, CD105. They also found that these multipotent mesenchymal stem cells lack expression of HLA-DR, DP, DQ (MHC class II) and EMA. Another study by Gronthos et al. [48] reported that Human adipose tissue-derived stromal cells lack the expression of STRO-1 marker [48]. Positive expression STRO-1 marker was identified by Zuk et al. [50], Miura et al. [51], Kadar et al. [56], Gronthos et al. [63], Gronthos et al. [64], Stewart et al. [65], Simmons et al. [66] and Walsh et al. [68]. Igura et al. [21] found that placenta-derived mesenchymal progenitor cells (PDMPC) express CD105; HLA class I and lack expression of HLA-DR. Zuk et al. [50] reported that mesenchymal stem cells were $\mathrm{SH} 2(+), \mathrm{SH} 3(+)$. Parte et al. [52] found putative stem cells of menopausal human ovarian surface epithelium to be positive for pluripotent gene transcripts Oct-4, Oct-4A, Nanog, Sox-2, TERT, Stat-3. Yu et al. [55] reported that there is a low expression of CD45 and CD44 in Adipose-derived 
Table 1. Summary of the Relevant Studies

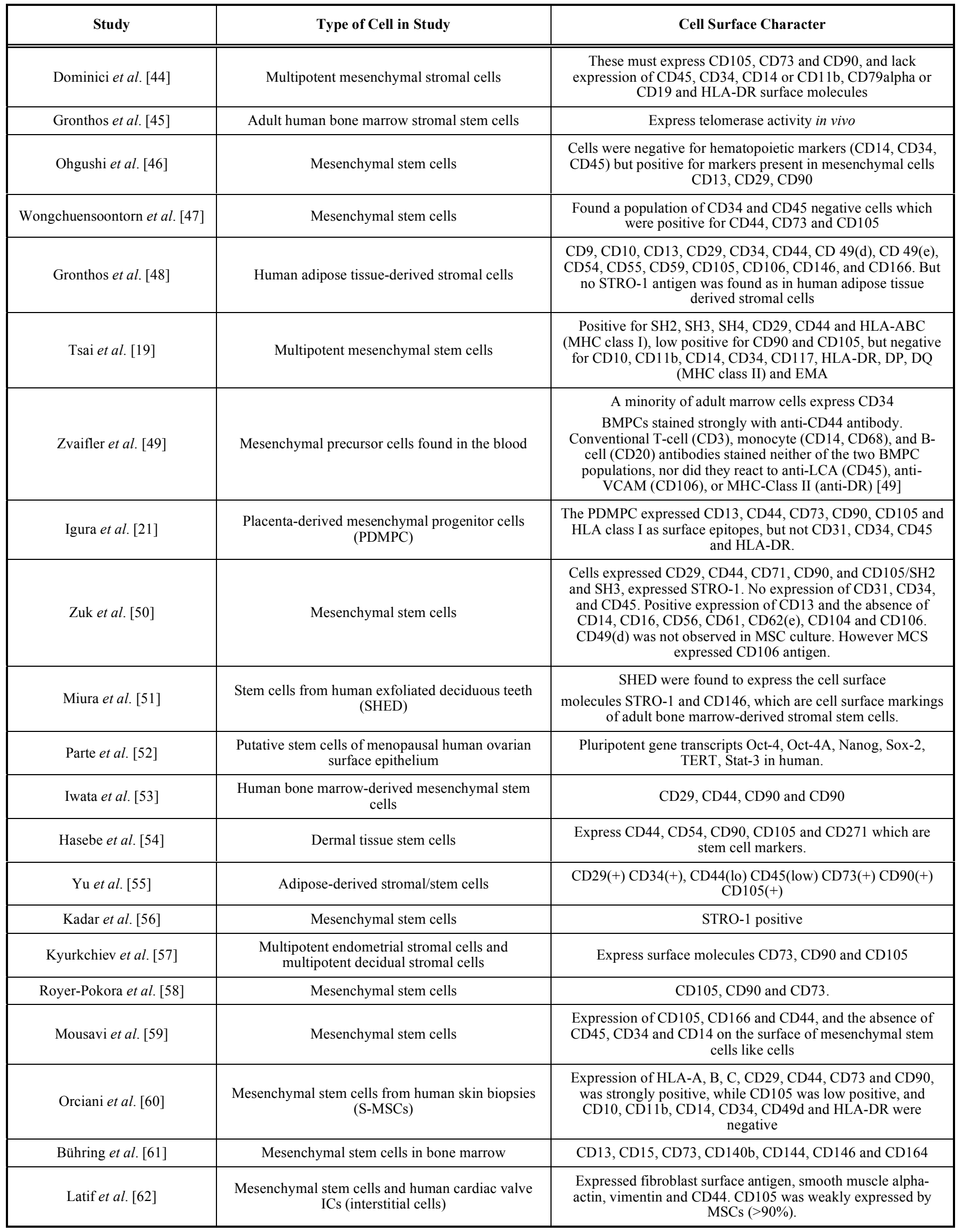


(Table 1) contd.....

\begin{tabular}{|c|c|c|}
\hline Study & Type of Cell in Study & Cell Surface Character \\
\hline \hline Gronthos et al. [63] & Bone marrow derived stromal progenitor cells & STRO-1 positive \\
\hline Gronthos et al. [64] & Stromal cells derived from the bone marrow & STRO-1 positive \\
\hline Stewart et al. $[65]$ & Bone marrow-derived mesenchymal stem cells & STRO-1 positive \\
\hline Simmons and Torok-Storb [66] & $\begin{array}{c}\text { BM-derived mesenchymal stem cells STRO-1 } \\
\text { positive + CD34 positive }\end{array}$ & STRO-1 positive, CD34 positive \\
\hline Simmons et al. [67] & Bone marrow derived mesenchymal stem cells & CD106 positive, CD34 positive \\
\hline Walsh et al. $[68]$ & Bone marrow-derived mesenchymal stem cells & STRO-1 positive \\
\hline Conget and Minguell [69] & Human bone marrow mesenchymal progenitor cells & $\begin{array}{c}\text { Express integrin subunits alpha4, alpha5, beta1, integrins } \\
\text { alphavbeta3 and alphavbeta5, ICAM-1, and CD44H. These } \\
\text { were CD49d (-) and CD34 (-). }\end{array}$ \\
\hline Pittenger et al. [6] & Adult human mesenchymal stem cells & CD49d (-), CD106 (+), CD34 (-) \\
\hline
\end{tabular}

stromal/stem cells (ASC). Orciani et al. [60] identified the MSCs from human skin biopsies (S-MSCs) to be positive for HLA-A, B, C, and low positive for 105 and negative for HLA-DR. Latif et al. [62] reported mesenchymal stem cells to be positive for fibroblast surface antigen, smooth muscle alpha-actin, vimentin and low positive for CD105. Zvaifler et al. [49] found that only a minority of bone marrow cells expressed CD34. Conget and Minguell [69] reported the expression of integrin subunits alpha4, alpha5, beta1, integrins alphavbeta3 and alphavbeta5, ICAM-1, and $\mathrm{CD} 44 \mathrm{H}$ in human bone marrow mesenchymal progenitor cells.

\section{DISCUSSION}

In this systematic review we have looked at the cell surface characterization of adult mesenchymal stem cells. We have found that CD105, CD90, CD44, CD73, CD29, CD13, CD34, CD146, CD106, CD54 and CD166 rank among the most commonly reported positive cell surface markers on mesenchymal cells. There are, however, a number of cell surface markers that have been reported as being absent in mesenchymal stem cells. The most frequently reported are CD34, CD14, CD45, CD11b, CD49d, CD106, CD10 and CD31. In addition to these, a number of other cell surface markers have been identified. These are STRO-1, SH2, SH3, SH4, HLA-A, HLA-B, HLAC, HLA-DR, HLA-I, DP, EMA, DQ (MHC Class II), CDIO5, Oct 4, Oct 4A, Nanog, Sox-2, TERT, Stat-3, fibroblast surface antigen, smooth muscle alpha-actin, vimentin, integrin subunits alpha4, alpha5, beta1, integrins alphavbeta3 and alphavbeta5 and ICAM-1 [19, 21, 50, 50$52,56,60,62-66,68,69]$. Eight studies have confirmed the expression of STRO-1on bone marrow-derived mesenchymal stem cells [50, 51, 56, 63-66, 68]. However, Gronthos et al. [48] has reported adipose tissue-derived stromal cells to be STRO-1 negative. This suggests the difference in the expression of STRO-1 depending on whether they are adipose tissue-derived or bone marrow derived; nevertheless it should be noted that these represent only about $3 \%$ of the bone marrow stromal population [ 48 , 63-68]. Positive expression of $\mathrm{SH} 2$ and $\mathrm{SH} 3$ has been

Table 2. Summary of Positive Cell Surface Markers of Mesenchymal Stem Cells

\begin{tabular}{|c|c|c|c|c|c|c|c|c|c|c|c|c|c|c|c|c|c|c|c|c|c|c|c|c|}
\hline Study & CD9 & CD10 & CD13 & CD15 & CD29 & CD34 & CD44 & CD44h & CD45 & CD49(d) & CD49(e) & CD54 & CD55 & CD71 & CD73 & CD90 & CD105 & CD106 & CD140(b) & CD144 & CD146 & CD164 & CD166 & CD271 \\
\hline Dominici et al. [44] & & & & & & & & & & & & & & & CD73 & CD90 & CD105 & & & & & & & \\
\hline Ohgushi et al. [46] & & & CD13 & & CD29 & & & & & & & & & & & CD90 & & & & & & & & \\
\hline Wongchuensoontorn et al. [47] & & & & & & & CD44 & & & & & & & & $\mathrm{CD} 73$ & & CD105 & & & & & & & \\
\hline Gronthos et al. [48] & CD9 & CD10 & CD13 & & CD29 & CD34 & CD44 & & & CD49(d) & CD49(e) & CD54 & CD55 & & & & CD105 & & & & CD146 & & CD166 & \\
\hline Tsai et al. [19] & & & & & CD29 & & CD44 & & & & & & & & & CD90 & CD105 & & & & & & & \\
\hline Zvaifler et al. [49] & & & & & & CD34 & & & & & & & & & & & & & & & & & & \\
\hline Igura et al. [21] & & & CD13 & & & & CD44 & & & & & & & & CD73 & CD90 & CD105 & & & & & & & \\
\hline Zuk et al. [50] & & & CD13 & & $\mathrm{CD} 29$ & & CD44 & & & & & & & CD71 & & CD90 & CD105 & & & & & & & \\
\hline Miura et al. [51] & & & & & & & & & & & & & & & & & & & & & CD146 & & & \\
\hline Iwata et al. [53] & & & & & $\mathrm{CD} 29$ & & CD44 & & & & & & & & & CD90 & & & & & & & & \\
\hline Hasebe et al. [54] & & & & & & & CD44 & & & & & CD54 & & & & CD90 & CD105 & & & & & & & CD271 \\
\hline Yu et al. [55] & & & & & CD29 & CD34 & CD44 & & $\mathrm{CD} 45$ & & & & & & CD73 & CD90 & CD105 & & & & & & & \\
\hline Kyurkchiev et al. [57] & & & & & & & & & & & & & & & CD73 & CD90 & CD105 & & & & & & & \\
\hline Royer-Pokora et al. [58] & & & & & & & & & & & & & & & CD73 & CD90 & CD105 & & & & & & & \\
\hline Mousavi et al. [59] & & & & & & & CD44 & & & & & & & & & & CD105 & & & & & & CD166 & \\
\hline Orciani et al. [60] & & & & & CD29 & & CD44 & & & & & & & & CD73 & CD90 & CD105 & & & & & & & \\
\hline Bühring et al. [61] & & & $\mathrm{CD} 13$ & CD15 & & & & & & & & & & & CD73 & & & & CD140(b) & CD144 & CD146 & CD164 & & \\
\hline Latif et al. [62] & & & & & & & CD44 & & & & & & & & & & & & & & & & & \\
\hline Simmons PJ, Torok-Storb B [66] & & & & & & CD34 & & & & & & & & & & & & & & & & & & \\
\hline Simmons et al. [67] & & & & & & CD34 & & & & & & & & & & & & CD106 & & & & & & \\
\hline Conget et al. [69] & & & & & & & & CD44h & & & & & & & & & & & & & & & & \\
\hline Pittenger et al. [6] & & & & & & & & & & & & & & & & & & CD106 & & & & & & \\
\hline
\end{tabular}


Table 3. Summary of Negative Cell Surface Markers and Mesenchymal Stem Cells

\begin{tabular}{|c|c|c|c|c|c|c|c|c|c|c|c|c|c|c|c|c|c|c|c|c|c|c|c|c|}
\hline Stud y & CD3 & CD10 & CD11b & CD14 & CD16 & CD19 & CD31 & CD34 & CD35 & CD36 & CD38 & CD44 & CD45 & CD49 & CD49d & CD50 & CD56 & CD61 & CD62(E) & CD68 & CD79a & CD104 & CD106 & CD117 \\
\hline Dominici et al. [44] & & & CD11b & CD14 & & CD19 & & CD34 & & & & & CD45 & & & & & & & & CD79 $\alpha$ & & & \\
\hline Ohgushi et al. [46] & & & & CD14 & & & & CD34 & CD35 & & & & & & & & & & & & & & & \\
\hline Wongchuensoontorn et al. [47] & & & & & & & & CD34 & & & & & CD45 & & & & & & & & & & & \\
\hline Tsai et al. [19] & & CD10 & CD11b & CD14 & & & & CD34 & & & & & & & & & & & & & & & & CD117 \\
\hline Zvaifler et al. [49] & $\mathrm{CD} 3$ & & & CD14 & & & & & & & & CD44 & $\mathrm{CD} 45$ & & & & & & & CD68 & & & CD106 & \\
\hline Igura et al. [21] & & & & & & & $\mathrm{CD} 31$ & CD34 & & & & & $\mathrm{CD} 45$ & & & & & & & & & & & \\
\hline Zuk et al. [50] & & & & CD14 & CD16 & & CD31 & CD34 & & & & & CD45 & & CD49d & & CD56 & CD61 & CD62(E) & & & CD104 & CD106 & \\
\hline Mousavi et al. [59] & & & & CD14 & & & & CD34 & & & & & CD45 & & & & & & & & & & & \\
\hline Orciani et al. [60] & & CD10 & CD11b & CD14 & & & & CD34 & & & & & & CD49 & & & & & & & & & & \\
\hline Conget et al. [69] & & & & & & & & CD34 & & & & & & & CD49d & & & & & & & & & \\
\hline Pittnger et al. [6] & & & & & & & & CD34 & & & & & & & CD49d & & & & & & & & & \\
\hline
\end{tabular}

confirmed by Tsai et al. [19] and Zuk et al. [50]. Igura et al. [21] Tsai et al. [19] and Orciani et al. [60] have all confirmed that mesenchymal stem cells are HLA-DR negative. Orciani et al. [60] and Latif et al. [62] have both stated that there was low expression of CD105. Another interesting finding in this systematic review is that several studies have reported conflicting findings about the cell surface markings of mesenchymal stem cells. These cells were identified as CD10 (+) by Gronthos et al. [45], but as CD10 (-) by Tsai et al. [19] and Orciani et al. [60]. Similarly Gronthos et al. [45], Zvaifler et al. [49] and Yu et al. [55] identified the cells as CD34 (+) whereas Dominici et al. [44], Ohgushi et al. [46], Wongchuensoontorn et al. [47], Tsai et al. [19], Igura et al. [21], Zuk et al. [50], Mousavi et al. [59] and Orciani et al. [60] found these to be CD34 (-).

Table 4. The Mesenchymal Cell Positive Surface Markers and the Number of Studies where they have been Reported

\begin{tabular}{|c|c|}
\hline CD105 & 12 \\
\hline CD90 & 11 \\
\hline CD44 & 11 \\
\hline CD73 & 8 \\
\hline CD29 & 7 \\
\hline CD13 & 5 \\
\hline CD34 & 5 \\
\hline CD146 & 3 \\
\hline CD106 & 2 \\
\hline CD54 & 2 \\
\hline CD166 & 2 \\
\hline CD9 & 1 \\
\hline CD10 & 1 \\
\hline CD15 & 1 \\
\hline CD45 & 1 \\
\hline CD49d & 1 \\
\hline $\mathrm{CD} 49 \mathrm{e}$ & 1 \\
\hline CD55 & 1 \\
\hline CD71 & 1 \\
\hline CD140b & 1 \\
\hline CD144 & 1 \\
\hline CD164 & 1 \\
\hline CD271 & 1 \\
\hline CD44h & 1 \\
\hline
\end{tabular}

Table 5. The Cell Surface Markers that have been Reported as being Absent on Mesenchymal Stem Cells and the Number of Studies that Reported this

\begin{tabular}{|c|c|}
\hline CD34 & 10 \\
\hline CD14 & 7 \\
\hline CD45 & 6 \\
\hline $\mathrm{CD} 11 \mathrm{~b}$ & 3 \\
\hline CD49d & 3 \\
\hline CD106 & 2 \\
\hline CD10 & 2 \\
\hline CD31 & 2 \\
\hline CD62e & 1 \\
\hline CD68 & 1 \\
\hline CD117 & 1 \\
\hline CD19 & 1 \\
\hline CD3 & 1 \\
\hline CD16 & 1 \\
\hline CD35 & 1 \\
\hline CD44 & 1 \\
\hline CD49 & 1 \\
\hline CD56 & 1 \\
\hline CD61 & 1 \\
\hline CD104 & 1 \\
\hline $\operatorname{CD} 79 \alpha$ & 1 \\
\hline
\end{tabular}

In a study to identify the mesenchymal precursor cells in the blood of normal individuals, Zvaifler and colleagues reported on interesting observations. They found that only a minority of these cells express the CD34 surface antigen [49]. They also reported that only $5 \%$ of marrow cells reacted with Stro- 1 antigen which is one of the defining features of bone marrow MSCs $[49,66]$. Moreover, Zvaifler et al. stated that the colony forming unit fibroblasts expressed much lower levels of CD34 compared to human hematopoietic stem cells [49]. Other studies have found that CD34 is also expressed on vascular endothelial cells, basement membrane structures, and dendritic and perifollicular cells in human skin $[70,71]$. Simmons and Torok-Storb used the expression of CD34 marker to separate human bone marrow cells [72]. As suggested by Zvaifler et al. the difference in findings concerning the CD34 antigen could be because all the studies mentioned above were 
conducted on MSCs before the culture [49]. The same stromal cells after culture, in vivo, do not react with CD34 antibodies anymore [72]. Similarly, despite having been identified in the endothelial cells of human umbilical vein, they have not been found in vitro [73]. According to these results we can conclude that the CD34 expression of these cells is highly disputed $[74,75]$.

CD44 is another cell surface marker that has been identified as positive $[19,21,45,47,50,53-55,59,60,62]$ and negative [49]. Yu et al. [55] stated that adult mesenchymal stem cells are CD45 positive as opposed to findings by Dominici et al. [44], Wongchuensoontorn et al. [47], Zvaifler et al. [49], Igura et al. [21], Zuk et al. [50] and Mousavi et al. [59] where they have been reported as CD45 negative.

It is important to note that $\mathrm{Yu}$ et al. [55] reported adult MSCs to express low levels of CD44 and CD45. Gronthos et al. [45] found the cells to be CD49d positive, whereas Zuk et al. [50] reported them to be CD49d negative. Finally, Simmons et al. [67] and Pittenger et al. [6] have identified mesenchymal stem cells as CD106 positive but, Zvaifler et al. [49] and Zuk et al. [50] have found them to be CD106 negative.

A possible explanation for the conflicting results obtained in different papers reviewed is provided in a study conducted by Gronthos and colleagues where gene and protein expression of human adipose tissue-derived stromal cells in their differentiated and undifferentiated states is described. The results obtained were then compared to those of bone marrow stromal cells as previously defined in the literature. As already mentioned in this paper, they found that the expression of surface antigen in adipose tissuederived stromal cells is not identical to that of bone marrowderived stromal cells [48]. In this study, two different explanations for the discrepancy in the results have been suggested. Firstly, they argue that these differences may be due to different proliferative stages of the cells in culture [48]. Furthermore, they also state that donor heterogeneity could be of importance when comparing adipose tissuederived stromal cells with those derived from the bone marrow [48].

In this systematic review we have managed to look at many different studies which discuss the different cell surface markers of adult MSCs. According to the literature reviewed, we can say that there is great discrepancy between the existence and expression of many cell surface markers including CD10, CD34, CD44, CD45, CD49d and CD106, which at times makes it difficult to summarize the available evidence in order to establish a set of clear-cut criteria for identifying these cells. As mentioned earlier, there may be different reasons as to why the expression of these surface markers differs in a number of studies. However, we suggest that further research is needed to identify the cell surface profile of adult MSCs. One possibility would be to choose adult MSCs of the same origin, say bone marrow-derived MSCs, and compare their surface characteristics under the same conditions as other reviews have already provided. Subsequently, the characteristics of a group of cells of the same origin should be assessed under different conditions, such as before and after culture, to observe whether there is any change in the expression of surface markers.
While we hope to have established a good reference for identifying the cell surface markers on adult mesenchymal stem cells, it is important to point out some limitations of this systematic review. 1) The reported cell surface characteristics in the studies reviewed were not all derived from the same tissue. Some were bone marrow-derived $[45 ; 50 ; 51 ; 53 ; 56 ; 61 ; 63-66 ; 68]$, some from skin $[54 ; 60]$ and others from endometrium [57], adipose tissue [48;55], ovaries [52], deciduous teeth [51] and many other sources. 2) Some of the studies included were not specifically aimed at identifying the cell surface markers of adult mesenchymal cells. These studies simply included the surface markings that were identified or compared to other cells. 3) There were fewer studies looking at the negative surface markers of mesenchymal stem cells compared to those identifying the positive cell surface markers. 4) Despite the fact that there are not plenty of studies commenting on identifying adult mesenchymal stem cells, we could argue that the number of studies reviewed is not very large and thus the results need to be interpreted with care.

\section{CONCLUSION}

In this systematic review we have summarized the available research evidence concerning the cell surface profile of adult mesenchymal stem cells. The findings have been presented in Tables 1-5. Different studies have identified various positive and negative surface markers for mesenchymal stem cells. Interestingly, several studies have reported conflicting information about some of the cell surface markers including CD10, CD34, CD44, CD45, CD49d and CD106. We can conclude that the expression of some surface antigens, such as STRO-1, is dependent on whether the cells are adipose tissue-derived or bone marrowderived. Another factor accounting for the variability in the expression of adult MSC surface markers could be the different stages during cell proliferation and culture where the markers have been accessed. Despite the exhaustive findings of this systematic review, the conflicting evidence and inadequate information about several cell surface markers, we suggest that further research in this field is necessary.

\section{ACKNOWLEDGEMENT}

None declared.

\section{CONFLICT OF INTEREST}

None declared.

\section{REFERENCES}

[1] Prockop DJ. Marrow stromal cells as stem cells for nonhematopoietic tissues. Science 1997; 276(5309): 71-4.

[2] Friedenstein AJ, Chailakhjan RK, Lalykina KS. The development of fibroblast colonies in monolayer cultures of guinea-pig bone marrow and spleen cells. 3: 393-403. Cell Tissue Kinet 1970; 3: 393-403.

[3] Bianco P, Robey PG, Simmons PJ. Mesenchymal stem cells: revisiting history, concepts, and assays. Cell Stem Cell 2008; 2(4): 313-9.

[4] Caplan AI. Adult mesenchymal stem cells for tissue engineering versus regenerative medicine. J Cell Physiol 2007; 213(2): 341-7.

[5] Kolf CM, Cho E, Tuan RS. Mesenchymal stromal cells. Biology of adult mesenchymal stem cells: regulation of niche, self-renewal and differentiation. Arthritis Res Ther 2007; 9(1): 204. 
[6] Pittenger MF, Mackay AM, Beck SC, et al. Multilineage potential of adult human mesenchymal stem cells. Science 1999; 284(5411): 143-7.

[7] Simmons PJ, Przepiorka D, Thomas ED, Torok-Storb B. Host origin of marrow stromal cells following allogeneic bone marrow transplantation. Nature 1987; 328(6129): 429-32.

[8] Friedenstein AJ. Stromal mechanisms of bone marrow: cloning in vitro and retransplantation in vivo. Haematol Blood Transfus 1980; 25: 19-29.

[9] Ratajczak MZ, Zuba-Surma EK, Machalinski B, Kucia M. Bonemarrow-derived stem cells--our key to longevity? J Appl Genet 2007; 48(4): 307-19.

[10] Asahara T, Takahashi T, Masuda H, et al. VEGF contributes to postnatal neovascularization by mobilizing bone marrow-derived endothelial progenitor cells. EMBO J 1999; 18(14): 3964-72.

[11] Jiang Y, Jahagirdar BN, Reinhardt RL, et al. Pluripotency of mesenchymal stem cells derived from adult marrow. Nature 2002; 418(6893): 41-9.

[12] Reyes M, Lund T, Lenvik T, Aguiar D, Koodie L, Verfaillie CM. Purification and ex vivo expansion of postnatal human marrow mesodermal progenitor cells. Blood 2001; 98(9): 2615-25.

[13] D'Ippolito G, Diabira S, Howard GA, Menei P, Roos BA, Schiller PC. Marrow-isolated adult multilineage inducible (MIAMI) cells, a unique population of postnatal young and old human cells with extensive expansion and differentiation potential. J Cell Sci 2004; 117(Pt 14): 2971-81.

[14] Crisan M, Yap S, Casteilla L, et al. A perivascular origin for mesenchymal stem cells in multiple human organs. Cell Stem Cell 2008; 3(3): 301-13.

[15] Rogers I, Casper RF. Umbilical cord blood stem cells. Best Pract Res Clin Obstet Gynaecol 2004; 18(6): 893-908.

[16] Bieback K, Kluter H. Mesenchymal stromal cells from umbilical cord blood. Curr Stem Cell Res Ther 2007; 2(4): 310-23.

[17] Xu Y, Malladi P, Wagner DR, Longaker MT. Adipose-derived mesenchymal cells as a potential cell source for skeletal regeneration. Curr Opin Mol Ther 2005; 7(4): 300-5.

[18] Shi S, Gronthos S. Perivascular niche of postnatal mesenchymal stem cells in human bone marrow and dental pulp. J Bone Miner Res 2003; 18(4): 696-704.

[19] Tsai MS, Lee JL, Chang YJ, Hwang SM. Isolation of human multipotent mesenchymal stem cells from second-trimester amniotic fluid using a novel two-stage culture protocol. Hum Reprod 2004; 19(6): 1450-6.

[20] Bi Y, Ehirchiou D, Kilts TM, et al. Identification of tendon stem/progenitor cells and the role of the extracellular matrix in their niche. Nat Med 2007; 13(10): 1219-27.

[21] Igura K, Zhang X, Takahashi K, Mitsuru A, Yamaguchi S, Takashi TA. Isolation and characterization of mesenchymal progenitor cells from chorionic villi of human placenta. Cytotherapy 2004; 6(6): 543-53.

[22] De BC, Dell'Accio F, Tylzanowski P, Luyten FP. Multipotent mesenchymal stem cells from adult human synovial membrane. Arthritis Rheum 2001; 44(8): 1928-42.

[23] Takashima Y, Era T, Nakao K, et al. Neuroepithelial cells supply an initial transient wave of MSC differentiation. Cell 2007; 129(7): 1377-88.

[24] Nagoshi N, Shibata S, Kubota Y, et al. Ontogeny and multipotency of neural crest-derived stem cells in mouse bone marrow, dorsal root ganglia, and whisker pad. Cell Stem Cell 2008; 2(4): 392-403.

[25] Schipani E, Kronenberg HM. Adult mesenchymal stem cells. Stembook 2008; doi: 10.3824/stembook.1.38.1.

[26] Tsutsumi S, Shimazu A, Miyazaki K, et al. Retention of multilineage differentiation potential of mesenchymal cells during proliferation in response to FGF. Biochem Biophys Res Commun 200; 288(2): 413-9.

[27] Kulterer B, Friedl G, Jandrositz A, et al. Gene expression profiling of human mesenchymal stem cells derived from bone marrow during expansion and osteoblast differentiation. BMC Genomics 2007; 8: 70 .

[28] Pochampally RR, Smith JR, Ylostalo J, Prockop DJ. Serum deprivation of human marrow stromal cells (hMSCs) selects for a subpopulation of early progenitor cells with enhanced expression of OCT-4 and other embryonic genes. Blood 2004; 103(5): 1647-52.

[29] Hishikawa K, Miura S, Marumo T, et al. Gene expression profile of human mesenchymal stem cells during osteogenesis in three- dimensional thermoreversible gelation polymer. Biochem Biophys Res Commun 2004; 317(4): 1103-7.

[30] Kratchmarova I, Blagoev B, Haack-Sorensen M, Kassem M, Mann M. Mechanism of divergent growth factor effects in mesenchymal stem cell differentiation. Science 2005; 308(5727): 1472-7.

[31] Song L, Webb NE, Song Y, Tuan RS. Identification and functional analysis of candidate genes regulating mesenchymal stem cell selfrenewal and multipotency. Stem Cells 2006; 24(7): 1707-18.

[32] Phinney DG, Prockop DJ. Concise review: mesenchymal stem/multipotent stromal cells: the state of transdifferentiation and modes of tissue repair--current views. Stem Cells 2007; 25(11): 2896-902.

[33] Ortiz LA, Dutreil M, Fattman C, et al. Interleukin 1 receptor antagonist mediates the antiinflammatory and antifibrotic effect of mesenchymal stem cells during lung injury. Proc Natl Acad Sci USA 2007; 104(26): 11002-7.

[34] Kunter U, Rong S, Djuric Z, et al. Transplanted mesenchymal stem cells accelerate glomerular healing in experimental glomerulonephritis. J Am Soc Nephrol 2006; 17(8): 2202-12.

[35] Minguell JJ, Erices A. Mesenchymal stem cells and the treatment of cardiac disease. Exp Biol Med (Maywood ) 2006; 231(1): 39-49.

[36] Lee RH, Seo MJ, Reger RL, et al. Multipotent stromal cells from human marrow home to and promote repair of pancreatic islets and renal glomeruli in diabetic NOD/scid mice. Proc Natl Acad Sci USA 2006; 103(46): 17438-43.

[37] Phinney DG, Isakova I. Plasticity and therapeutic potential of mesenchymal stem cells in the nervous system. Curr Pharm Des 2005; 11(10): 1255-65.

[38] Prockop DJ. "Stemness" does not explain the repair of many tissues by mesenchymal stem/multipotent stromal cells (MSCs). Clin Pharmacol Ther 2007; 82(3): 241-3.

[39] Le BK, Ringden O. Immunobiology of human mesenchymal stem cells and future use in hematopoietic stem cell transplantation. Biol Blood Marrow Transplant 2005; 11(5): 321-34.

[40] Horwitz EM, Gordon PL, Koo WK, et al. Isolated allogeneic bone marrow-derived mesenchymal cells engraft and stimulate growth in children with osteogenesis imperfecta: Implications for cell therapy of bone. Proc Natl Acad Sci USA 2002; 99(13): 8932-7.

[41] Nixon AJ, Goodrich LR, Scimeca MS, Witte TH, Schnabel LV, Watts AE, et al. Gene therapy in musculoskeletal repair. Ann NY Acad Sci 2007; 1117: 310-27.

[42] Castro-Malaspina H, Gay RE, Resnick G, et al. Characterisation of human bone marrow fibroblast colony-forming cells (CFU-F) and their progeny. Blood 1980; 56: 289-301.

[43] Civin CI, TrischmannT, Kadan NS, et al. Highly purified CD34positive cells reconstitute hematopoiesis. J Clin Oncol 1996; 14(8): 2224-33.

[44] Dominici M, Le BK, Mueller I, et al. Minimal criteria for defining multipotent mesenchymal stromal cells. The International Society for Cellular Therapy position statement. Cytotherapy 2006; 8(4): 315-7.

[45] Gronthos S, Zannettino AC, Hay SJ, et al. Molecular and cellular characterisation of highly purified stromal stem cells derived from human bone marrow. J Cell Sci 2003; 116(Pt 9): 1827-35.

[46] Ohgushi H, Kotobuki N, Funaoka H, et al. Tissue engineered ceramic artificial joint--ex vivo osteogenic differentiation of patient mesenchymal cells on total ankle joints for treatment of osteoarthritis. Biomaterials 2005; 26(22): 4654-61.

[47] Wongchuensoontorn C, Liebehenschel N, Schwarz U, et al. Application of a new chair-side method for the harvest of mesenchymal stem cells in a patient with nonunion of a fracture of the atrophic mandible--a case report. J Craniomaxillofac Surg 2009; 37(3): 155-61.

[48] Gronthos S, Franklin DM, Leddy HA, Robey PG, Storms RW, Gimble JM. Surface protein characterization of human adipose tissue-derived stromal cells. J Cell Physiol 2001; 189(1): 54-63.

[49] Zvaifler NJ, Marinova-Mutafchieva L, Adams G, et al. Mesenchymal precursor cells in the blood of normal individuals. Arthritis Res 2000; 2(6): 477-88.

[50] Zuk PA, Zhu M, Ashjian P, et al. Human adipose tissue is a source of multipotent stem cells. Mol Biol Cell 2002; 13(12): 4279-95.

[51] Miura M, Gronthos S, Zhao M, et al. SHED: stem cells from human exfoliated deciduous teeth. Proc Natl Acad Sci USA 2003 ; 100(10): 5807-12.

[52] Parte SC, Bhartiya D, Telang J, et al. Detection, Characterization and Spontaneous Differentiation in vitro of Very Small Embryonic- 
like Putative Stem Cells in Adult Mammalian Ovary. Stem Cells Dev 2011 [Epub ahead of print].

[53] Iwata $\mathrm{T}$, Yamato $\mathrm{M}$, Zhang $\mathrm{Z}$, et al. Validation of human periodontal ligament-derived cells as a reliable source for cytotherapeutic use. J Clin Periodontol 2010; 37(12): 1088-99.

[54] Hasebe Y, Hasegawa S, Hashimoto N, et al. Analysis of cell characterization using cell surface markers in the dermis. J Dermatol Sci 2011; 62(2): 98-106.

[55] Yu G, Wu X, Dietrich MA, et al. Yield and characterization of subcutaneous human adipose-derived stem cells by flow cytometric and adipogenic mRNA analyzes. Cytotherapy 2010; 12(4): 538-46.

[56] Kadar K, Kiraly M, Porcsalmy B, et al. Differentiation potential of stem cells from human dental origin - promise for tissue engineering. J Physiol Pharmacol 2009; 60(Suppl 7): 167-75.

[57] Kyurkchiev S, Shterev A, Dimitrov R. Assessment of presence and characteristics of multipotent stromal cells in human endometrium and decidua. Reprod Biomed Online 2010; 20(3): 305-13.

[58] Royer-Pokora B, Busch M, Beier M, et al. Wilms tumor cells with WT1 mutations have characteristic features of mesenchymal stem cells and express molecular markers of paraxial mesoderm. Hum Mol Genet 2010; 19(9): 1651-68.

[59] Mousavi NN, Jaberipour M, Razmkhah M, Ghaderi A, Habibagahi M. Mesenchymal stem cells do not suppress lymphoblastic leukemic cell line proliferation. Iran J Immunol 2009; 6(4): 186-94.

[60] Orciani M, Mariggio MA, Morabito C, Di BG, Di PR. Functional characterization of calcium-signaling pathways of human skinderived mesenchymal stem cells. Skin Pharmacol Physiol 2010; 23(3): 124-32.

[61] Buhring HJ, Treml S, Cerabona F, de ZP, Kanz L, Sobiesiak M. Phenotypic characterization of distinct human bone marrowderived MSC subsets. Ann N Y Acad Sci 2009; 1176: 124-34.

[62] Latif N, Sarathchandra P, Thomas PS, et al. Characterization of structural and signaling molecules by human valve interstitial cells and comparison to human mesenchymal stem cells. J Heart Valve Dis 2007; 16(1): 56-66.

[63] Gronthos S, Graves SE, Ohta S, Simmons PJ. The STRO-1+ fraction of adult human bone marrow contains the osteogenic precursors. Blood 1994; 84(12): 4164-73.

[64] Gronthos S, Zannettino AC, Graves SE, Ohta S, Hay SJ, Simmons PJ. Differential cell surface expression of the STRO-1 and alkaline phosphatase antigens on discrete developmental stages in primary cultures of human bone cells. J Bone Miner Res 1999; 14(1): 4756.

[65] Stewart K, Walsh S, Screen J, et al. Further characterization of cells expressing STRO-1 in cultures of adult human bone marrow stromal cells. J Bone Miner Res 1999; 14(8): 1345-56.

[66] Simmons PJ, Torok-Storb B. Identification of stromal cell precursors in human bone marrow by a novel monoclonal antibody, STRO-1. Blood 1991; 78(1): 55-62.

[67] Simmons PJ, Gronthos S, Zannettino A, Ohta S, Graves S. Isolation, characterization and functional activity of human marrow stromal progenitors in hemopoiesis. Prog Clin Biol Res 1994; 389: 271-80.

[68] Walsh S, Jefferiss C, Stewart K, Jordan GR, Screen J, Beresford JN. Expression of the developmental markers STRO-1 and alkaline phosphatase in cultures of human marrow stromal cells: regulation by fibroblast growth factor (FGF)-2 and relationship to the expression of FGF receptors 1-4. Bone 2000; 27(2): 185-95.

[69] Conget PA, Minguell JJ. Phenotypical and functional properties of human bone marrow mesenchymal progenitor cells. J Cell Physiol 1999; 181(1): 67-73.

[70] Nickoloff BJ. The human progenitor cell antigen (CD34) is localized on endothelial cells, dermal dendritic cells, and perifollicular cells in formalin-fixed normal skin, and on proliferating endothelial cells and stromal spindle-shaped cells in Kaposi's sarcoma. Arch Dermatol 1991; 127(4): 523-9.

[71] Brown J, Greaves MF, Molgaard HV. The gene encoding the stem cell antigen, CD34, is conserved in mouse and expressed in haemopoietic progenitor cell lines, brain, and embryonic fibroblasts. Int Immunol 1991; 3(2): 175-84.

[72] Simmons PJ, Torok-Storb B. CD34 expression by stromal precursors in normal human adult bone marrow. Blood 1991; 78(11): 2848-53.

[73] Fina L, Molgaard HV, Robertson D, et al. Expression of the CD34 gene in vascular endothelial cells. Blood 1990; 75(12): 2417-26.

[74] Fernandez M, Simon V, Herrera G, Cao C, Del FH, Minguell JJ. Detection of stromal cells in peripheral blood progenitor cell collections from breast cancer patients. Bone Marrow Transplant 1997; 20(4): 265-71.

[75] Bucala R, Spiegel LA, Chesney J, Hogan M, Cerami A. Circulating fibrocytes define a new leukocyte subpopulation that mediates tissue repair. Mol Med 1994; 1(1): 71-81.

(C) Mafi et al.; Licensee Bentham Open.

This is an open access article licensed under the terms of the Creative Commons Attribution Non-Commercial License (http://creativecommons.org/licenses/by-nc/3.0/) which permits unrestricted, non-commercial use, distribution and reproduction in any medium, provided the work is properly cited. 